\title{
ANALYSIS OF RESTAURANT TAX EFFECTIVENESS ON THE ORIGINAL REVENUE OF MANADO CITY
}

\author{
Farida Indria Sanly Wakidin \\ Department of Accounting, Polytechnic of Manado Country \\ DOI: 10.31364/SCIRJ/v7.i11.2019.P1119726 \\ http://dx.doi.org/10.31364/SCIRJ/v7.i11.2019.P1119726
}

\begin{abstract}
The purpose of this research was to analyze the effectiveness of restaurant tax receipts on Manado City's original income. The original income of the city of Manado is the income that is obtained by the region which is collected based on local regulations in accordance with the laws and regulations. One component of the contributors in the structure of local revenue is the local tax. Restaurant tax is a type of local tax that is levied as a source of regional income. The research method used in this research is descriptive qualitative method, namely by analyzing the restaurant tax effectiveness in 2014-2018. The analytical tool used is the Manado City regional tax revenue data. The results of this study indicate that the level of effectiveness of restaurant tax revenue in 2014-2018 is always successful, achieving the specified targets and having different criteria. In 2016 the highest level of effectiveness, while the lowest level of effectiveness was in 2014. With an average of the realization of restaurant tax of $116.92 \%$, and entered the category of very effective. It is necessary to inform the public that the funds collected are used to help regional interests by increasing development in general, so that taxpayers become motivated to pay taxes, so that the effectiveness of restaurant tax on Manado City's original income is increased.
\end{abstract}

Keywords: Local Original Revenue, Effectiveness, Restaurant Tax

\section{INTRODUCTION}

Since the enactment of regional autonomy, each region must be able to regulate and manage all regional government affairs independently. Based on Law Number 23 of 2014 concerning Regional Government. With regional autonomy, the region is expected to be able to progress and develop independently by developing a variety of potentials in the area, which is sourced from the original regional income. The most important source of financing is the source of financing from local own-source revenue, where the main component is revenue derived from the local tax component, regional levies, the results of the management of separated regional assets, and other legitimate local-original revenue. Regional original income is an indicator of success in the implementation of regional autonomy. The higher role of regional own-source revenue in regional revenue is a reflection of the success of regional businesses, in financing governance and development. One contributing component in the structure of Local Revenue is the Regional Tax.

Tax is a regional levy according to regulations stipulated to finance regional expenditures as a public legal entity regulated in Law Number 28 of 2009 concerning Regional Taxes and Regional Retribution. The results of the tax collection itself can be returned to the community through the development of facilities and infrastructure in order to advance and improve regional welfare. Regional Tax is divided into two types, namely Provincial Tax and Regency or City Tax. The Provincial Tax consists of 5 types of taxes, namely Motorized Vehicle Tax, Motorized Vehicle Transfer Fee Duty, Surface Water Tax, and Cigarette Tax, while Regency or City Tax consists of 11 tax types, namely Hotel Tax, Restaurant Tax, Entertainment Tax, Advertisement Tax, Road Lighting Taxes, NonLogan and Rock Mineral Taxes, Parking Taxes, Groundwater Taxes, Swallow Bird Nest Taxes, Land and Building Taxes for Rural and Urban Buildings, and Land and Building Acquisition Fees. This is done to make it easier for local governments to determine local tax rates and calculations according to their types based on applicable laws and regulations. Therefore, local taxes must be managed professionally and transparently in the context of optimization and efforts to increase effectiveness and contribution to Regional Original Revenues. One of the significant contributors to Local Revenue is Restaurant Tax.

Restaurant Tax is a tax on services provided by restaurants, while restaurant is a facility providing food and beverages with a fee, which also includes restaurants, cafeterias, canteens, stalls, bars, and the like, including catering / catering services. Manado City Government in this case the Regional Revenue Agency, every year has a target in receiving Restaurant Taxes, but within 5 years, restaurant tax receipts always exceed the targets set by the Manado City Government. To optimize restaurant tax collection, it is necessary to calculate regional tax revenue more precisely and accurately. Based on the description above, the researchers are interested in conducting a study of the effectiveness of restaurant tax under the title "Analysis of Restaurant Tax Effectiveness Against the Original Revenue of the City of Manado. 


\section{RESEARCH METHODS}

\subsection{Types of research}

This type of research used in this study is qualitative by conducting data studies in descriptive or descriptive form. This study describes the realization of restaurant taxes, calculating and analyzing the effectiveness of restaurant tax on Local Revenue using a case study approach.

\subsection{Data source}

Data sources used in this study are:

1. Primary data sources are data directly collected by researchers from the source directly. As for the primary data source in this study, obtained from interviews with employees, and the head of the financial sub-section in the form of a detailed list of receipts of the Original Revenue of the city of Manado.

2. Secondary data sources are data obtained through intermediary media in the form of documents, government regulations, books, and other supporting data obtained from search results on the internet.

\subsection{Data collection technique}

The data collection methods used in this research are:

1. Field Study

a. Interview Technique

This interview was conducted directly with employees at the Manado City Regional Revenue Service to obtain the data needed in the research.

b. Documentation Techniques

Data collection with this method, namely to retrieve the documents needed in this study, in the form of a detailed list of Manado City Regional Tax revenues.

2. Literature review

Conduct library study methods by reading, and studying books and similar research. In addition, researchers also searched several internet sites for data collection, and information related to the issues discussed in this study.

\subsection{Data analysis technique}

The analytical method used in this research is descriptive analysis and effectiveness analysis.

1. Descriptive Analysis

According to Sugiyono (2013) Descriptive analysis is an analysis that collects, collects, processes, and analyzes numerical data, so that it can provide a picture of a particular situation so that conclusions can be drawn.

2. Effectiveness Analysis

Effectiveness is used to measure the relationship between the results of a tax levy with the goals or targets that have been set. It is said to be effective if the activity process reaches the goals, and the final goal of the policy. To analyze the effectiveness of Restaurant Tax, the researchers used the formula:

$$
\text { Effectiveness }=\frac{\text { Realization of restaurant tax receipts }}{\text { Restaurant tax revenue target }} \times 100 \%
$$

\section{History}

\section{DISCUSSION}

The Regional Revenue Service has changed its name to the Regional Tax and Retribution Management Agency. This name change occurred since the existence of Regional Regulation Number 2 of 2016, and Mayor Regulation Number 61 of 2016 of the Manado City Revenue Service, has officially been renamed the Manado City Regional Tax and Retribution Management Agency, hereinafter abbreviated as the Tax and Retribution Management Agency Area. This name change, carried out in accordance with the provisions of Article 5 of Government Regulation Number 2 of 2016 concerning the Formation and Arrangement of Regional Apparatus of the City of Manado, so that it is necessary to stipulate a Mayor Regulation concerning the position, organizational structure, duties and functions, and work procedures. The Regional Tax and Retribution Management Agency, continues to carry out its functions and duties as in the regional revenue service in the past, namely to carry out the supporting functions of the financial sector in the sub-sector of Regional Tax and Retribution Management. In 2019 the Regional Tax and Retribution Management Agency, changed its name to the Manado City Regional Revenue Agency, due to the Manado Mayor Regulation No. 11 of 2019 
regarding the position, composition, organization, duties and functions as well as the work procedures of the Manado City Regional Revenue Agency

\section{The Task of the Manado City Regional Revenue Agency}

To assist the Mayor in carrying out the supporting functions of government affairs in the field of tax and retribution management.

\section{Function of Regional Revenue Agency of Manado City}

In carrying out its tasks, the Manado City Regional Revenue Agency has the following functions:

a. Preparation of technical policies in accordance with the scope of their duties

b. Implementation of technical support tasks in accordance with the scope of their duties

c. Monitoring, evaluating and reporting the implementation of tasks. Technical guidance in the implementation of supporting functions of Government Affairs in accordance with the scope of their duties. Implementation of other functions provided by the Mayor in accordance with the scope of their duties.

\section{Vision and Mission of the Manado City Regional Revenue Agency}

a. Vision Serve with SMART: Fast, Efficient, Friendly, Dedicated, Accountable and Smiling.

b. Mission

Building a city that has "competitiveness" with an orientation towards increasing investment attractiveness and quality of public services based on information and communication technology.

\section{Goals and Objectives of Manado City Regional Revenue Agency}

a. Purpose of Manado City Regional Revenue Agency

1) Increasing the realization of Regional Original Revenue to support governance and regional development.

2) Improving the quality of Human Resources, facilities and infrastructure of the apparatus. Orderly administration arrangements and accountable.

b. Goals of the Manado City Regional Revenue Agency.

1) The realization of professional regional financial management.

2) Increasing the efficiency and effectiveness of using a balanced budget and oriented to the public interest.

3) The realization of order in the regional financial administration.

Improving the understanding of all apparatus resources towards the main tasks and functions in the field of data collection, registration, determination, billing and accounting of regional taxes and user charges carried out in accordance with the system and information technology based procedures.

\section{A. Restaurant Tax Object Data}

The object of restaurant tax is the service provided by the restaurant. Services provided by the restaurant include the sale of food and beverages consumed by the buyer, both consumed at the service and other places. A restaurant is a food and beverage service provider that is free of charge, which includes restaurants, cafeterias, canteens, food stalls, bars, catering / catering services and the like. Based on data in the Manado City Regional Revenue Agency, restaurant tax objects are divided into 2 categories, namely restaurants and restaurants, in the restaurant category the tax collected is only restaurants, while for restaurants including tax objects, the rest of the restaurant category. The following is the restaurant tax object data in the city of Manado in 2014-2018. The following is the restaurant tax revenue data obtained, from research in the Manado City Revenue Agency in 2014 - 2018.

Table 3.1 Manado City Restaurant Tax Object in 2014-2018

\begin{tabular}{|c|c|c|c|}
\hline Year & Restaurant & Food Stalls & $\begin{array}{c}\text { Amount } \\
\text { Taxpayer }\end{array}$ \\
\hline 2014 & 240 & 245 & 385 \\
\hline 2015 & 165 & 154 & 487 \\
\hline 2016 & 176 & 311 & 519 \\
\hline 2017 & 194 & 325 & 510 \\
\hline
\end{tabular}

Source: Manado City Regional Revenue Agency, 2019 


\section{B. Restaurant Tax Revenue Data}

The following is the restaurant tax revenue data obtained from research in the Manado City Regional Revenue Agency in 2014 - 2018

Table 3.2 Target and Realization of Manado City Restaurant Tax in 2014-2018

\begin{tabular}{|c|c|c|}
\hline Year & Target (IDR) & Realization (IDR) \\
\hline 2014 & 38.550 .000 .000 & 40.401 .504 .799 \\
\hline 2015 & 42.000 .000 .000 & 67.469 .492 .846 \\
\hline 2016 & 47.500 .000 .000 & 71.905 .821 .095 \\
\hline 2017 & 56.800 .000 .000 & 78.829 .486 .501 \\
\hline 2018 & 70.000 .000 .000 & \\
\hline
\end{tabular}

Source: Manado City Regional Revenue Agency, 2019

Based on Table 3.2 above shows the restaurant tax target in 2014 which was set at IDR.38,550,000,000, while the realization reached the target of IDR. 40,401,50,7,799. In 2015 the restaurant tax target was set at IDR.42,000,000,000 and its realization reached the target of IDR.47,469,492,846. In 2016, the restaurant tax target will be IDR.47,500,000,000 while the realization has increased from the previous year of IDR.60,607,630,932. In 2017 the restaurant tax target is IDR.5,800,000 and its realization has increased by IDR7,905,821,095. In 2018 the target will increase by IDR 70,000,000,000 while the realization will not increase much more than the previous year with a realization of IDR. 78,829,486,501.

\section{Data Details on Realization of Restaurant Taxes}

The following is detailed realization data from the realization of restaurant tax in 2014-2018 can be seen in the table below.

Table 3.3 Details of Realization of Restaurant Tax in 2014-2018

\begin{tabular}{|c|c|c|c|c|}
\hline Year & Category & Realization (IDR) & $\begin{array}{c}\text { Percentage } \\
(\%)\end{array}$ & $\begin{array}{c}\text { Amount } \\
\text { (IDR) }\end{array}$ \\
\hline \multirow{2}{*}{2014} & Restaurant & \multirow{2}{*}{40.401 .504 .799} & 51,85 & 20.948 .180 .238 \\
\hline & Food Stalls & & 48,15 & 19.453 .324 .561 \\
\hline \multirow{2}{*}{2015} & Restaurant & \multirow{2}{*}{47.469 .492 .846} & 58,45 & 27.745 .918 .568 \\
\hline & Food Stalls & & 41,55 & 19.723 .574 .278 \\
\hline \multirow{2}{*}{2016} & Restaurant & \multirow{2}{*}{60.607 .630 .932} & 46,10 & 27.940 .117 .860 \\
\hline & Food Stalls & & 53,10 & 32.667 .513 .072 \\
\hline \multirow{2}{*}{2017} & Restaurant & \multirow{2}{*}{71.905 .821 .095} & 47,30 & 34.011 .453 .378 \\
\hline & Food Stalls & & 52,70 & 37.894 .367 .717 \\
\hline \multirow{2}{*}{2018} & Restaurant & \multirow{2}{*}{78.829 .486 .501} & 37,97 & 29.931 .556 .024 \\
\hline & Food Stalls & & 62,03 & 48.897 .930 .477 \\
\hline
\end{tabular}

Source: Manado City Regional Revenue Agency, 2019

\section{Analysis of the Manado City Restaurant Tax Effectiveness}

By knowing the level of effectiveness, the Manado city government can find out the targets that have been achieved in restaurant tax revenue in the city of Manado. The following is a table of the effectiveness of restaurant tax revenue in the city of Manado in 2014-2018.

Table 3.4 Effectiveness of Manado City Restaurant Tax Receipts in 2014-2018

\begin{tabular}{|c|c|c|c|}
\hline Year & Target (IDR) & Realization (IDR) & Percentage of Effectiveness (\%) \\
\hline 2014 & 38.550 .000 .000 & 40.401 .504 .799 & 104,80 \\
\hline 2015 & 42.000 .000 .000 & 47.469 .492 .846 & 113,02 \\
\hline
\end{tabular}




\begin{tabular}{|c|c|c|c|}
\hline 2016 & 47.500 .000 .000 & 60.607 .630 .932 & 127,60 \\
\hline 2017 & 56.800 .000 .000 & 71.905 .821 .095 & 126,59 \\
\hline 2018 & 70.000 .000 .000 & 78.829 .486 .501 & 112,61 \\
\hline \multicolumn{2}{|l|}{ Average Restaurant Tax Percentage } & 116,92 \\
\hline
\end{tabular}

Source: Processed Data, 2019

From the data above shows the percentage of the effectiveness of Restaurant Tax revenue in 2014 was $104.80 \%$, in 2015 it was $113.02 \%$, in $2016127.60 \%$, in 2017 was $126.59 \%$, and in 2018 it was $112.61 \%$. With an average percentage of effectiveness of $116.92 \%$. Below is a calculation to find out the effectiveness of restaurant tax revenue using the formula, as follows:

$$
\begin{gathered}
\text { Effectiveness }=\frac{\text { "Realization of Restaurant Tax Receipts }}{\text { "Restaurant tax revenue target" }} \times 100 \% \\
\text { Effectiveness of } 2014=\frac{40.401 .504 .799}{38.550 .000 .000} \times 100 \%=104,80 \% \\
\text { Effectiveness of } 2015=\frac{47.469 .492 .846}{42.000 .000 .000} \times 100 \%=113,02 \% \\
\text { Effectiveness of } 2016=\frac{60.607 .630 .932}{47.500 .000 .000} \times 100 \%=127,59 \% \\
\text { Effectiveness of } 2017=\frac{71.905 .821 .095}{56.800 .000 .000} \times 100 \%=126,59 \% \\
\text { Effectiveness of } 2018=\frac{78.829 .486 .501}{70.000 .000 .000} \times 100 \%=112,61 \%
\end{gathered}
$$

From the above calculation it can be seen that the parking tax revenue in 2014-2018, each year reaches the target set by the Manado city government. From the results of calculations of effectiveness in 2014, 2015, 2016, 2017 and 2018 information can be obtained as follows:

1. In 2014 restaurant tax revenue is targeted at IDR 38,550,000,000 with the realization of IDR $1,851,504,799$ or $4.80 \%$.

2. In 2015 restaurant tax revenue is targeted at IDR 3,450,000,000 or $8.94 \%$ from the previous year and the realization has increased by IDR.5,469,492,846 or $13.02 \%$. If seen from Table 3.1 the number of taxpayers has decreased by 166 Taxpayers from the previous year due to the restaurant business and food stalls have put in place a system of calculating their own taxes and no longer use the tax assessment system. Although the number of taxpayers decreased, restaurant tax revenues increased more than in the previous year, as revenues from restaurants and food stalls increased.

3. In 2016, restaurant tax revenue is targeted to be greater than the previous year of IDR5,500,000,000 or $13.09 \%$. With such an increase, the realization of restaurant tax increased higher than the previous year of IDR 13,107,630,932 or 27.59\%. In 2016 the number of taxpayers increased by about 168 taxpayers from the previous year because taxpayers had begun to get used to the selftaxation system that was set in 2015. Although the number of taxpayers rose, their income also rose because in 2014 the number of taxpayers was 485 and in 2016 there were 487 taxpayers. So with the addition of 2 taxpayers, it is possible that the income in 2016 has greatly increased from the previous year and also by the compliance of the culinary entrepreneurs to the rules for paying restaurant tax which is set at $10 \%$ of the price, making the revenue from restaurant taxes also increase

4. In 2017 restaurant tax revenue is targeted to be greater than the previous year, which is IDR. 9,300,000,000 or $19.57 \%$. With the raised target from the previous year the realization of the restaurant tax still reached the target set and exceeded it by IDR. $15,105,821,095$ or $26.59 \%$. If seen from Table 3.1 the number of taxpayers, it increased by 32 taxpayers. Thus, the increase in the number of income taxpayers from the taxpayers also rose, and affected the tax revenue of restaurants in the regional revenue agency. With the existence of a good regional income from the restaurant tax sector, shows the development of culinary businesses going well in the city of Manado. Increasingly high income from the restaurant tax sector, shows that many people come and culinary tours in the city of Manado.

5. In 2018 the target set has increased more than the previous year of IDR 9,300,000,000 to IDR $13,200,000,000$ or $23.23 \%$, with an increase in the target, the revenue received from restaurant tax will continue to reach the target set by the city government experienced an increase in realization of IDR 8,829,486,501 or $12.61 \%$. Even though restaurant tax revenue has reached the target, the increase is not like the previous year. Due to a decrease in taxpayers, automatic restaurant tax receipts from culinary entrepreneurs also declined. However, if seen from the previous year, restaurant tax revenue this year has decreased because it is caused by the lack of other taxpayers in depositing the proceeds from the income. With the results obtained from restaurant tax receipts from 2014-2018, they have different levels of effectiveness and are categorized as very effective levels. This can be known based on the categories that have been determined and obtained the results of the effectiveness of local taxes, as shown in the table below. From the above calculation it can be seen that the parking tax revenue in 2014-2018, each year reaches the target 
set by the city of Manado. From the results of calculations of effectiveness in 2014, 2015, 2016, 2017 and 2018 information can be obtained as follows:

1. In 2014 restaurant tax revenue is targeted at IDR 38,550,000,000 with the realization of IDR 1,851,504,799 or $4.80 \%$.

2. In 2015 restaurant tax revenue is targeted at IDR 3,450,000,000 or $8.94 \%$ from the previous year and the realization has increased by IDR 5,469,492,846 or $13.02 \%$. If seen from Table 3.1 the number of taxpayers decreased by 166 taxpayers from the previous year, because the restaurant and food stall businesses had put in place a system of calculating their own taxes, and no longer used the tax assessment system. Although the number of taxpayers has decreased, restaurant tax revenues have increased more than in the previous year, as revenues from restaurants and food stalls increased.

3. In 2016, restaurant tax revenue is targeted to be greater than the previous year of IDR 5,500,000,000 or $13.09 \%$. With such an increase, the realization of restaurant tax increased higher than the previous year of IDR 13,107,630,932 or 27.59\%. In 2016 the number of taxpayers increased by about 168 taxpayers from the previous year, because taxpayers had begun to get used to the system of calculating their own tax, which was set in 2015. Although the number of taxpayers rose, their income also rose, because in 2014 the number There are 485 taxpayers, and in 2016 there were 487 taxpayers. So with the addition of 2 taxpayers, it is possible that the income in 2016 will greatly increase from the previous year, and also with the compliance of culinary entrepreneurs to the rules for paying restaurant tax which is set at $10 \%$ of the price, making the revenue from restaurant taxes also increase .

4. In 2017 restaurant tax revenue is targeted to be greater than the previous year, which is IDR. 9,300,000,000 or $19.57 \%$. With the raised target from the previous year, the realization of restaurant tax still reached the target set, and exceeded it by IDR. $15,105,821,095$ or $26.59 \%$. If seen from Table 3.1 the number of taxpayers rose by 32 taxpayers. Thus, the increase in the number of income taxpayers from the taxpayers also rose, and had a good effect on restaurant tax receipts at the local revenue agency. With the good regional income from the restaurant tax sector, it shows that the development of culinary business is going well in Manado. Increasingly high income from the restaurant tax sector, shows that many people come, and have a culinary tour in the city of Manado.

5. In 2018 the target is set to have a greater increase than the previous year, amounting to IDR. 9,300,000,000 to IDR. $13,200,000,000$ or $23.23 \%$, with an increase in the target, the revenue received from restaurant tax will still reach the target, with a realization increase of IDR. $8,829,486,501$ or $12.61 \%$. Although the restaurant tax revenue reached the specified target, but the increase did not, as in the previous year due to a slight decrease in taxpayers, then automatically the restaurant tax revenue from culinary entrepreneurs also declined. However, if seen from the previous year, restaurant tax revenue this year, has decreased because it is caused by the lack of other taxpayers, in depositing the results of these revenues.

With the results obtained from restaurant tax receipts from 2014-2018, they have different levels of effectiveness and are categorized as very effective levels. This can be known based on the categories that have been determined, and obtained the results of the effectiveness of local taxes, as shown in the table below.

\section{CONCLUSION}

The level of effectiveness of restaurant tax revenues in 2014-2018 always achieves the specified targets and has different criteria. For restaurant tax receipts in 2014 with the achievement of a target exceeding 100\% of what was targeted was $104.80 \%$ with a very effective category. In 2015 the percentage results increased from $104.80 \%$ to $113.02 \%$ with a very effective category. In 2016 there was a target achievement, and an increase of $127.60 \%$ in the very effective category. In 2017 restaurant tax revenue decreased slightly, which was in the previous year from $127.60 \%$ to $126.59 \%$ with a very effective category. And in 2018 the results of the percentage has decreased, namely from $126.59 \%$ to $112.61 \%$ but with a decrease in percentage results may not be an obstacle because it is still considered very effective. With an average of restaurant tax realization of $116.92 \%$ and included in the category of very effective. In 2016, the highest level of restaurant tax effectiveness was $127.60 \%$ while the lowest was in 2014 amounting to $104.80 \%$, although in 2014 it was classified as low but still included in the very effective category.

\section{REFERENCES}

Lamia, Alfan. 2015. Analisis Efektivitas Dan Kontribusi Pemungutan Pajak Restoran, Pajak Reklame, Dan Pajak Penerangan Jalan Pada Pendapatan Asli Daerah Kabupaten Minahasa Utara. https://ejournal.unsrat.ac.id/index.php/jbie/article/view/10474

Lengkong, Vanessa Angela. 2016. Analisis Efektivitas Realisasi Pajak Hotel Dan Kontribusinya Terhadap Pendapatan Asli Daerah Pada Dinas Pendapatan Daerah Kota Bitung. https://ejournal.unsrat.ac.id/index.php/jbie/article/view/13585

Mahmudi. 2019. Analysis of Regional Government Financial Statements, Yogyakarta : Sekolah Tinggi Ilmu Manajemen YKPN.

Mardiasmo. 2016. Taxation. Yogyakarta : Andi.

Siahaan, Marihot Pahala. Regional Taxes and Regional Retribution. Jakarta : PT. Rajagrafindo Persada. 
Sari Diana. 2013. Basic Concepts of Taxation. Bandung : PT. Refika Aditama.

Sugiyono. 2014. Quantitative, Qualitative Research Methods, and R\&D.. Bandung : Alfabeta.

Law Number 28 of 2009 concerning Regional Taxes and Regional Retribution.

Law Number 33 of 2004 concerning Financial Balance between Central and Regional Governments 